\title{
O pragmatyzmie językowym w Szwajcarii w kontekście języka angielskiego: perspektywa makro-socjolingwistyczna
}

Słow a klu c ze: socjologia języka; postawy językowe; pragmatyzm językowy; Szwajcaria

Ke y w o r d s: sociology of language; language attitudes; language pragmatism; Switzerland

\section{Makro-socjolingwistyka: wprowadzenie do socjologii języka}

W socjolingwistyce przyjęto podział na socjolingwistykę właściwą w węższym znaczeniu, która bada strukturę i funkcje języka będące pod wpływem społecznym, oraz na socjologie języka, która uwydatnia rolę języka w społeczeństwie i polityce. Te dwie perspektywy dają możliwość przyglądania się wielu odmiennym choć powiązanym ze sobą zjawiskom. Innymi słowy, socjolingwistyka w skali mikro dotyczy „społecznych aspektów języka” czyli bada język w odniesieniu do społeczeństwa, natomiast socjolingwistyka w skali makro skupia się na ,językowych aspektach społeczeństwa”, biorąc pod lupę społeczeństwo w relacji do języka (Coulmas 1997: 2). W takim ujęciu socjolingwistyka i socjologia języka stanowią dwa końce tego samego kontinuum. Ponieważ w niniejszym artykule przyjęłam podejście do 
omawianego problemu na poziomie makro analizy językowej i społecznej, w związku z tym w usprawiedliwiony sposób pominę aspekty związane z mikro-socjolingwistyką.

Socjologia języka bada kulturowe i polityczne podejście do języków, politykę językową i planowanie języka w odniesieniu do władzy i językowego braku równowagi. Fishman (1997: 25) uważa, że podstawowym przedmiotem zainteresowania socjologii języka jest społeczna organizacja zachowań językowych, w tym nie tylko języka jako takiego, ale również jawne postawy wobec języka i jego użytkowników. Można przyjąć, że socjologia języka zajmuje się faktami językowymi na trzech poziomach. Pierwszy poziom to opis zachowań językowych. Na poziomie drugim analizuje się reakcje ludzi na owe zachowania językowe. Natomiast poziom trzeci dotyczy opinii na temat tychże zachowań oraz związanych z nimi reakcjami. Widać stąd, że poszukiwanie schematów współzależności między językiem i społeczeństwem stanowi główny przedmiot dociekań socjologii języka.

W ramach przyjętej perspektywy, skupię się na wybranych zagadnieniach wpływających na pragmatyczne podejście do języka. Oprócz niezbędnego nakreślenia skali rozprzestrzenienia się angielskiego i jego cech w nowym kontekście, wspomnieć należy także o motywacji i postawie językowej oraz zastanowić się, na czym polega wybór języka. Poniższe rozważania zwieńczone zostaną danymi z mojego badania przeprowadzonego w kantonie Zurych na reprezentatywnej próbie 400 respondentów. W szczególności interesować mnie będzie relacja znajomości języka angielskiego u niemieckojęzycznych Szwajcarów do ich opinii wyrażanych na temat tego języka.

\section{Język angielski w kontekście globalnym}

Osiągnąwszy rozmiar globalny, zastosowanie angielskiego stało się obecnie w porównywalnym stopniu udziałem zarówno rodzimych użytkowników tego języka, jak i tych, który nabyli znajomość angielskiego w procesie nauczania (Seidlhofer 2004: 211). Same demograficzne proporcje między rodzimymi i nierodzimymi użytkownikami angielskiego skłaniają do przyjęcia założenia, iż większość ludzi uczących się angielskiego będzie wchodziło w kontakt z innymi, także uczącymi się tego języka. Według Kirkpatricka (2006: 79), angielski jako lingua franca jest przywłaszczany przez każdego, kto się nim posługuje i potrafi wyrażać w nim swoje rodzime normy kultu- 
rowe. W związku z tym, lingua franca staje się modelem o wielu standardach $\mathrm{z}$ różnorodnymi cechami kulturowymi.

W podobnym tonie co Kirkpatrick (2006), Prcic (2003: 37) wprowadza terminologiczne innowacje do nazewnictwa związanego $\mathrm{z}$ angielskim, proponując „Angielski jako Znatywizowany Język Obcy” (skrót ang. ENFL), gdzie „określnik 'znatywizowany' podkreśla stan, w którym angielski obiektywnie i subiektywnie stał się częścią (wielu) rodzimych języków i kultur na świecie"'. Prcic (2003: 35), opisując światowy status angielskiego, wyróżnia trzy nowe językowe cechy, które upodabniają angielski do języka rodzimego i częściowo do języka drugiego, a przez to innego od pozostałych języków obcych. Te cechy to jego (1) szybka audiowizualna dostępność, (2) podwójne przyswajanie i (3) uzupełniająca funkcja językowa. Pierwsza cecha podkreśla wszechobecność angielskiego i jego dostępność w jednokierunkowej komunikacji. Druga cecha dotyczy przyswajania angielskiego w procesie formalnym i nieformalnym, co następuje jednocześnie i ma charakter wzajemnie się dopełniający. Z kolei, trzecia cecha wskazuje na język ojczysty z elementami angielskiego występującymi ,w obrębie języka rodzimego (na poziomie leksykalnym przez zapożyczenia), albo wraz z językiem rodzimym (poprzez tłumaczenie), albo nawet ponad językiem rodzimym (bez thumaczenia)" (Prcic 2003: 36).

\section{Pragmatyzm językowy}

Nauka języka wymaga motywacji i wykształca określone postawy językowe. Zaproponowano już wiele różnych modeli motywacji i postaw wobec języka. Ponadto, zaczęto postrzegać standardową odmianę języka jako kluczowy element kapitału kulturowego (por. Bourdieu 1991), czy też wymierną wartość ekonomiczną (por. Grin 2001). W niniejszym artykule pragmatyzm językowy przedstawiany jest jako całościowe podejście do warunków socjolingwistycznych, które dają pierwszeństwo konkretnemu językowi, pretendującemu do roli najlepszego narzędzia komunikacji. W opinii Zabrockiego (1972: 19), ocena określonych grup mownych przekłada się na ocenę języków, którymi owe grupy się posługują. Języki, które stają się narzędziem szerszej komunikacji w społecznościach, zyskują pewne umocowanie w róż-

1 Wszystkie cytaty z literatury obcojęzycznej zostały przetłumaczone na język polski przez autorkę niniejszego artykułu. 
nych sferach życia. Nawiązuje się szereg współzależności między danym językiem i domenami jego użycia. Cooper i Seckbach (1977: 213) zauważają, że w przypadku społeczności wielojęzycznych pozycja języka „po części zmienia się wraz z zakresem użycia podstawowych języków tej społeczności w dziedzinie literatury naukowo-technicznej, oraz po części wraz ze stopniem w jakim taka literatura odgrywa ważną rolę w funkcjonowaniu gospodarki”. I wreszcie, znaczenie języka szerszej komunikacji opiera się na rozmiarach dodatkowych funkcji, które język ten jest w stanie wypełniać.

\subsection{Motywacja językowa}

Użycie języka jest zasadniczo determinowane przez pragnienie posługiwania się nim przez indywidualnego użytkownika. McGroarty (1996: 30) sugeruje, że owemu pragnieniu powinna także towarzyszyć „,chęć do poświęcenia wysiłku w tym kierunku". Podobnie, Gardner (1985) widzi motywację jako połączenie pragnienia i wysiłku wkładanego w osiągnięcie celu. Warunki zewnętrzne mogą pozytywnie lub negatywnie wpływać na użycie języka, jednak ostatnie słowo w tej kwestii należy do konkretnego użytkownika. W przypadku języków zagrożonych, ich przetrwanie staje się wprost proporcjonalne do motywacji osób, które go kultywują. Cooper i Seckbach (1977: 212) wypowiadają się w podobnym tonie, uważając, że kiedy znajomość języka będzie powiązana z korzyścią materialną i kiedy ludzie dostaną szansę, by się go nauczyć, to wówczas skłonni są to zrobić.

Oczywisty jest fakt, iż język angielski rozwija się na bazie własnego potencjału komunikacyjnego, który sprawia, że ludzie decydują się na jego naukę i posługiwanie się nim. Jednak w kontekście Europy idea angielskiego jako języka drugiego nadal stanowi wyzwanie dla uświęconej tradycją europejskiej myśli dotyczącej analogii między językiem i tożsamością narodową (por. Graddol 2001: 50). Angielski stał się jedną z podstawowych umiejętności niezbędnych do osiągnięcia bardziej zaawansowanej i specjalistycznej wiedzy w przyszłości, innymi słowy, do ,uczenia jak się uczyć” (Graddol 2006: 72). Poza tym, niewątpliwie przyswajanie angielskiego, jego ról i funkcji, wpływa jeszcze bardziej na złożoność zachowań w wielojęzycznych społecznościach.

Według Zuengler (1989: 92), „wielu uczących się języka, (...) może wykazywać wyłącznie motywację instrumentalną, bądź też połączenie motywa- 
cji instrumentalnej i integracyjnej”. Motywacja instrumentalna wskazuje na wyraźną ambicję opanowania języka w konkretnym celu, najpewniej w celach zawodowych, natomiast motywacja integracyjna osadza się na pragnieniach i osobistych zainteresowaniach o charakterze socjalizacyjnym. Reasumując, należy zgodzić się z twierdzeniem Gardnera i Lamberta (1972: 142), że motywacja uczącego się jest kształtowana przez postawę i orientację wobec całego procesu nauki języka. Sugerują oni wyważone podejście powstałe na bazie obydwu typów motywacji do procesu uczenia się języka obcego, które powinno być świadomie rozwijane zwłaszcza w przypadku grup mniejszościowych.

\subsection{Postawy językowe}

Postawy językowe wymykają się przekonującej ocenie, gdyż zasadniczo są one wyrazem silnie subiektywnych systemów wartości i opinii. Postawa językowa jest węższym pojęciem niż postawa w ogóle, choć nie ogranicza się tylko do samego języka. Może dotyczyć innych językowych faktów zaliczanych do socjologii języka, takich jak zachowania językowe, albo reakcje i opinie o nich. Tym samym, postawy językowe dotyczą także postaw wobec użytkowników danego języka i mają raczej niewiele wspólnego ze stopniem językowej biegłości (por. Paulston 1988: 6). Co więcej, definicja postawy językowej jest często poszerzana, by objąć postawę danej osoby wobec innej, mówiącej innym językiem lub dialektem.

Postawa jako twór psychologiczny tworzy się w procesach socjalizacyjnych. Wyróżnia się trzy rodzaje elementów w ramach pojęcia postawy, które określa się jako kognitywne, emocjonalne i behawioralne (Garrett, Coupland i Williams 2006: 7), i które bada się na styku psychologii społecznej i socjolingwistyki. To właśnie psychologowie społeczni skłaniają się ku zgłębianiu nie tyle językowych zdolności, co raczej ku temu, jak uczący się języka postrzegają inne grupy językowe, a także ku ich postawom wobec członków tych grup, oraz ich gotowości do przejęcia językowych i niejęzykowych elementów zachowań. Niemniej jednak, umysłowe aspekty postaw zawsze były źródłem niepewności związanych z rzetelnością zbieranych danych. Obawa ta wzbudza niesłabnącą debatę (por. Kristiansen 2011).

W rezultacie, badania postaw językowych różnią się zakresem i sposobem pomiaru. Garrett (2007: 116-117) wymienia trzy podejścia badawcze. 
Jedno z nich określa się zazwyczaj jako podejście społecznościowe (societal treatment approach), które polega na prowadzeniu obserwacji. Pozostałe dwa podejścia są nazywane bezpośrednim (direct) lub pośrednim (indirect), ponieważ zajmują się danym problemem albo od wewnątrz, czyli od strony umysłu (mentalist), albo od zewnątrz, czyli z perspektywy behawioralnej (behaviourist).

Przykład definicji mentalistycznej został zaproponowany przez Williamsa (1974: 21), który uważa postawę za „stan wewnętrzny wywołany pewnego rodzaju pobudzeniem i który może wpływać na reakcję organizmu”. Ten punkt widzenia okazuje się jednak problematyczny w fazie eksperymentalnej. Wobec braku dającej się zaobserwować reakcji, ów stan wewnętrzny można badać jedynie za pomocą auto-raportów na temat postaw, lub domyślnie z zachowania osób badanych. Jednak wiarygodność danych pochodzących $\mathrm{z}$ auto-raportów jest często kwestionowana jako przeinaczająca prawdziwy obraz badanych postaw. Dlatego też, czynione są starania w badaniach nad postawami językowymi, by zmierzać do obmyślenia takich eksperymentów, których przebieg byłby nieuświadomiony przez osoby badane.

Z kolei, spojrzenie behawiorystyczne zakłada identyfikowanie postaw językowych w kontekście sytuacji społecznych, w których u osób badanych pojawiają się stosowne reakcje. Jedną z najbardziej znanych pośrednich metod badawczych pozwalających na zebranie danych o postawach językowych jest technika matched guise opracowana przez kanadyjskiego psychologa społecznego, Wallacea Lamberta. Zatem, tylko jawne zachowanie poddawane jest obserwacji, zestawieniom i analizom. Jednakże postawy definiowane w ten sposób nie mogą dawać podstawy do przewidywania innych typów zachowań, tak jak działoby się to w przypadku podejścia bezpośredniego (por. Agheyisi i Fishman 1970: 138).

\section{Wybór języka}

Można przyjąć, że motywacja i postawa językowa w przypadku indywidualnej osoby kształtuje się głównie w sferze umysłowej, natomiast późniejszy wybór konkretnego języka będzie raczej zamanifestowaniem podjętych wcześniej decyzji. Jeśli, z kolei, wybór języka oceniany jest w kontekście szerszej zbiorowości, to wówczas wchodzi w zakres polityki językowej. 
Według Fishmana (1972a: 451), charakterystyka wyboru języka uwidacznia się najlepiej w domenach, które są miejscem styku socjolingwistycznych aspektów zarówno w skali mikro, jak i makro. Domena definiowana jest jako „zorganizowany kontekst” (por. Farah 1997, Fishman 1972a) lub jako „regularności na dużą skalę o charakterze zbiorowym, które panują między odmianami językowymi i społecznie uznanymi funkcjami” (Fishman 1972b: 43). Tak rozumiana domena nie pozostaje bez wpływu na indywidualnego użytkownika języka. Jego wybór języka, stylu i kanału komunikacyjnego będzie podyktowany koniecznością wpasowania się w domenę, w obrębie której ma miejsce dane zdarzenie. A zatem, domena daje możliwość wglądu we wzorce komunikacyjne i wybory językowe w społeczeństwach wielojęzycznych. Dlatego właśnie Fishman (1972a: 437) twierdzi, że ,zwyczajowy wybór języka w wielojęzycznych społecznościach jest daleki od przypadkowej i chwilowej skłonności (...). 'Właściwe' użycie języka nakazuje wybór tylko jednego języka teoretycznie dostępnego spośród wielu, przez poszczególne warstwy rozmówców w określonych sytuacjach, by rozmawiać na określone tematy."

Według Spolsky’ego (2004: 43), wybór języka jest uwarunkowany „stopniem biegłości w danym języku (zero językowej wprawy uniemożliwia wybór), chęcią osiągnięcia korzyści przez użycie najlepiej opanowanego języka, oraz chęcią czerpania korzyści poprzez przystosowanie się do oczekiwań odbiorców". Gal (2007: 150) formułuje podobny pogląd i uzależnia decyzję o wyborze języka od ,czynników sytuacyjnych, (...) celu interakcji oraz języków, którymi posługują się dane osoby w kontakcie.” Z kolei, Nelde (1989: 79) dodaje do powyższej listy czynniki takie, jak „miejsce, w którym odbywa się kontakt, obecność innych znajomych lub nieznajomych osób, (...), środowisko społeczne, stopień zaufania, zamierzone wyrażenia i ocena własna w ramach wspólnoty językowej.” W słowach Fasolda (1984: 208), „wybór języka w konkretnym momencie jest dowodem pragnienia u danej osoby, aby być kojarzoną z wartościami tej czy innej społeczności mownej.” Tak więc, człowiek używa języka jako narzędzia uważanego przede wszystkim za środek do celu, którym jest komunikacja. Z kolei, język postrzegany jako środek identyfikacyjny albo jako językowa ojczyzna, jest raczej wynikiem kontrolowanego procesu językowej świadomości (por. Cathomas 1981). 


\subsection{Podejmowanie decyzji}

Jak wynika z powyższego, do zagadnienia wyboru języka można podejść z indywidualnej bądź zbiorowej perspektywy. Niemniej jednak, pierwszym skojarzeniem $z$ wyborem jako takim jest zawsze indywidualna osoba, bo to ona podejmuje decyzję, którego języka się uczyć. Wybór języka przez uczącego się odzwierciedla jego językowe zachowanie lub też jest wywołany jego „habitusem językowym” (linguistic habitus), który Bourdieu (1991) definiuje jako „zespół skłonności, które wywołują określoną akcję i reakcję u danej osoby." Zatem, postawy i praktyki zachowań są kształtowane przez „habitus językowy”. Spolsky (2004: 186) dodaje, że ów „habitus” „wywodzi się ze społecznego tła danej osoby, prowadząc do podobieństw wśród ludzi z tej samej klasy społecznej." W związku z tym, pewne aspekty wyboru językowego, czy też jego determinanty, mogą rzucać światło na warunki gospodarczo-polityczne lub po prostu na praktyczne rozwiązania komunikowania się w innych kontekstach (por. Herman 1970, Wardhaugh 2002: 97), choć społeczności mowne mogą różnić się strukturą wewnętrzną.

\subsection{Racjonalność w wyborze: przykład ze Szwajcarii}

Iso Camartin (1983) pisze o racjonalności związanej z użyciem języka w Szwajcarii i akcentuje niemiecki termin Rationalisierung, by zdefiniować nadrzędną zasadę stosowaną przez Szwajcarów w ich komunikacji werbalnej. I podaje przykład: kiedy spotka się dwóch fachowców z Lozanny i Zurychu, to aby porozmawiać, zdecydują się oni na wybór angielskiego, zamiast francuskiego czy niemieckiego. To, co w efekcie takiej sytuacji widzimy, to jest właśnie racjonalność, która jest nieprzejednanym wrogiem wszelkiej różnorodności i wielości (Camartin 1983: 18). To oznacza, że proste rozwiązania pojawiają się nie tylko tam, gdzie można zmaksymalizować korzyści, ale również dla wygody. Koncepcja racjonalności w kontaktach międzyludzkich dotyczy mniej lub bardziej wyszukanych rozwiązań po to, aby wyrażać się jasno i móc cieszyć się jednoznacznym zrozumieniem ze strony innych. Racjonalność rozumiana w ten sposób wynika sama z życiowych sytuacji i charakteryzuje się pewną dozą spontaniczności. Przeciętny Szwajcar nie wdaje się w dyskusje na temat problemów komunikacyjnych, gdyż nauczył się akceptować je jako nieodłączną część codzienności. Język dobiera się do 
konkretnej domeny życia i pracy bez świadomego poczucia przegranej jednego języka wobec drugiego. Niewłaściwym zabiegiem byłoby w ogóle posługiwać się retoryką z podtekstem rywalizacji w kontekście indywidualnych wyborów językowych podyktowanych wspólnymi uwarunkowaniami. Sama możliwość wyboru języka spośród wielu uważana jest za przywilej. Konkretny wybór języka zaspokaja potrzeby komunikacyjne, czy też raczej najważniejsze potrzeby, pozwalając na funkcjonowanie z poczuciem braku zaspokojenia potrzeb nieistotnych. Widać zatem, że znajomość tylko jednego języka musi wystarczyć do zaspokojenia wszystkich językowych potrzeb, podczas gdy wielojęzyczny repertuar pozwala na dostosowanie lub dobranie poszczególnych języków do różnych funkcji albo domen.

\section{Nota o badaniu: opinie na temat języka angielskiego $w$ kantonie Zurych}

W przypadku Szwajcarii znajomość języka angielskiego stała się standardem. Z jednej strony, posługiwanie się angielskim nie gwarantuje żadnych przywilejów, choć z drugiej strony, brak tej znajomości wyklucza lub poważnie ogranicza szanse społecznego i zawodowego awansu. Trzeba pamiętać, że Szwajcaria ma językowe alternatywy. Każdy z trzech oficjalnych języków to duży język europejski, którego znajomość daje możliwość porozumiewania się w Europie i na świecie. W Szwajcarii, kraju o silnych demokratycznych tradycjach i poszanowaniu prawa własności, panuje pewne uwrażliwienie, by nie narzucać sobie wzajemnie języków narodowych w kontaktach indywidualnych. W konsekwencji, Szwajcarzy coraz częściej sięgają po angielski jako lingua franca. Językowa różnorodność może być zatem uważana za jeden z powodów rozprzestrzeniania się angielskiego w Szwajcarii, obok innych korzyści, takich jak bodźce materialne i kulturowa afiliacja (por. Dürmüller 1986, 1989). W kontekście prowadzonych rozważań, możemy zapytać, dlaczego Szwajcarzy zaczęli sięgać po angielski w komunikacji wewnątrzkrajowej lub też co spowodowało zmianę statusu tego języka w ich kraju. Wiele artykułów Dürmüllera (1986, 1989, 1992, 1994, 2002), poświęconych angielskiemu w bezpośrednich kontaktach, prezentuje postawy i wybory językowe w wielojęzycznym społeczeństwie szwajcarskim. Co więcej, zagadnienia związane $z$ zachowaniem językowym, tj. postawy i opinie na temat angielskiego prezentowane przez Szwajcarów, moim zdaniem, kwali- 
fikują się do przeprowadzenia badania, którego podjęłam się na potrzeby niniejszego artykułu.

\subsection{Charakterystyka badania: metoda, próba i cel}

Badanie realizowane było od 28 czerwca do 20 lipca 2011 roku. Jako metodę badania wybrano wspomagany komputerowo wywiad telefoniczny (skrót ang. CATI). Metoda ta jest wykorzystywana do realizacji dużych, ilościowych projektów badawczych. Badanie zostało przeprowadzone ze studia telefonicznego należącego do Pracowni Badań Społecznych w Sopocie. Ogółem, przeprowadzono 400 pełnych wywiadów. Średnia długość jednego wywiadu wyniosła ostatecznie 6,6 minut. Podstawą badania było dobranie próby probabilistycznej, która jest reprezentatywna dla miasta i całego kantonu Zurych w kategorii cech demograficznych, a więc płci, wieku i poziomu wykształcenia. Wywiady przeprowadzono na podstawie przygotowanej ankiety składającej się z pytań zamkniętych. Szacowany błąd próby przy liczbie 400 respondentów wyniósł 5 procent.

Próba badawcza została scharakteryzowana na podstawie danych o płci, wieku, poziomie wykształcenia i zatrudnieniu. W badaniu wzięła udział podobna liczba kobiet i mężczyzn - odpowiednio 51\% i 49\%. Badałam pełnoletnich mieszkańców kantonu Zurych. Połowa respondentów to osoby między 35 a 54 rokiem życia. Badani powyżej 55 roku życia stanowili 38\%. Najmłodsza kategoria wiekowa, czyli osoby w wieku 18-34 lata, to 11\%. Niemal połowa badanych to osoby z wykształceniem podstawowym i niższym średnim. Druga w kolejności to grupa osób z wykształceniem wyższym (28\%). Wykształcenie średnie wyższe deklarował co piąty badany. Dwie trzecie ogółu badanych pracuje zawodowo (67\%).

Celem badania na użytek niniejszego artykułu jest analiza postaw i opinii mieszkańców niemieckojęzycznego kantonu Zurych wyrażanych wobec języka angielskiego i jego rosnącej obecności w Szwajcarii. Zebrane dane umożliwią mi także rozstrzygnięcie, w jakim stopniu badani Szwajcarzy znają język angielski i jak on wypada w ich opinii w kontekście czterech języków narodowych. 


\subsection{Wyniki badania}

Językiem ojczystym przeważającej grupy mieszkańców kantonu Zurych jest język niemiecki (78\%). Spośród osób, których język angielski nie jest językiem ojczystym, niemal 90\% badanych uczyło się języka angielskiego. Nieco częściej angielskiego uczą się kobiety niż mężczyźni (odpowiednio 90\% i 85\%). Nauka tego języka skorelowana jest z wiekiem badanych - spośród najmłodszej grupy wiekowej (18-34 lata) aż 98\% badanych zadeklarowało, że uczyło się angielskiego. Podobnie jest z poziomem wykształcenia im jest wyższe, tym więcej osób uczyło się języka angielskiego. Największa grupa mieszkańców kantonu deklaruje, że języka angielskiego uczyła się od 3 do 6 lat. Co ciekawe, sytuacja zawodowa badanych (pracujący/ niepracujący) nie różnicuje tego zagadnienia.

Według 89\% mieszkańców kantonu, potrzeba nauki języka angielskiego jest istotna. Połowa badanych chciałaby znać ten język lepiej, wśród najmłodszej grupy wiekowej jest to aż $70 \%$. Istotną rolę języka angielskiego potwierdzają też opinie badanych, gdyż uważają oni, że jego znajomość jest niezbędna (52\%) bądź bardzo ważna (44\%). Według dwóch trzecich badanych, rola języka angielskiego w kantonie będzie rosnąć. Jedna czwarta respondentów twierdzi, że pozostanie bez zmian, a jedynie niecałe $2 \%$, że się zmniejszy.

Badani poproszeni zostali o ocenę opinii dotyczących roli języka angielskiego w ich kraju. Niemal wszyscy badani zgodzili się, że umożliwiliby naukę języka swoim dzieciom (97\% łącznych odpowiedzi 'zdecydowanie tak' i 'raczej tak'). Podobny odsetek stwierdził, że znajomość języka angielskiego postrzegana jest w Szwajcarii jako atut. Blisko 90\% znających angielski zadeklarowało, że gdyby nie nauczyli się go w szkole bądź na uniwersytecie, staraliby się nauczyć go na własną rękę. Taki sam procent osób uważa, że angielski umożliwia im kontakt ze światem zewnętrznym, czyli poza Szwajcarią, oraz że wzmacnia kontakty międzyludzkie (89\%). Mniejsza liczba, ale nadal duża grupa badanych (aż 52\%!) zgodziła się ze stwierdzeniem, że angielski jest językiem bardziej użytecznym niż inne języki używane w Szwajcarii. Natomiast najmniej badanych podziela opinię, że angielski jest łącznikiem z rodakami zamieszkującymi inne regiony językowe Szwajcarii (38\%).

Podsumowując, badanie wykazało, że angielski cieszy się dużą popularnością i prestiżem wśród niemieckojęzycznych mieszkańców kantonu Zurych. Tylko co dziesiąty pytany o swoje doświadczenia z nauką angielskiego, 
stwierdzał, że nie miał z tym językiem nic wspólnego. Natomiast praktycznie całe młode pokolenie Szwajcarów nie wyobraża sobie funkcjonowania bez znajomości angielskiego. Pragmatyzm językowy w postawie respondentów był szczególnie widoczny w ocenie roli języka angielskiego w ich życiu. Troska nie tylko o własne wykształcenie językowe, ale również własnych dzieci, dotyczyła dziewięć na dziesięć osób pytanych o tę kwestię. Z kolei, przeświadczenie, iż angielski jest językiem o największym potencjale komunikacyjnym w skali świata stanowi niewątpliwie solidną bazę motywacyjną dla $90 \%$ respondentów. Ponadto, większość badanych wyraziła przekonanie, że w najbliższej przyszłości rola angielskiego będzie rosła. Opinia, że angielski funkcjonuje jako lingua franca $\mathrm{w}$ Szwajcarii byłaby przedwczesna, gdyż jak na razie porozumiewanie się wśród Szwajcarów z różnych regionów językowych odbywa się częściej w jednym z języków oficjalnych aniżeli w angielskim. Jednak niezależnie od wybranego języka, komunikacja spełniająca oczekiwania rozmówców jest zawsze dowodem na ich pragmatyzm językowy.

\section{Bibliografia}

Agheyisi R., Fishman J. A., 1970, Language attitude studies: A brief survey of methodological approaches, Anthropological Linguistics 12 (5), s. 137-157.

Bourdieu P., 1991, Language and symbolic power, Cambridge: Polity Press.

CAmartin I., 1983, Mehrsprachigkeit mit Vorteilen, Der Staatsbürger 5, s. 18-22.

Cathomas B., 1981, Die Einstellungen der Rätoromanen zum Schwyzertütsch, Bulletin CILA 33, s. 105-117.

Cooper R. L., Seсквасн F., 1977, Economic incentives for the learning of a language of wider communication: A case study, w: J. A. Fishman, R. L. Cooper, A. W. Conrad (red.), The spread of English: The sociology of English as an additional language, Rowley: Newbury House, s. 212-219.

Coulmas F. (red.), 1997, The handbook of sociolinguistics, Oxford: Blackwell.

DürmüLler U., 1986, The status of English in multilingual Switzerland, Bulletin CILA 44, s. 7-38.

DürmÜlLer U., 1989, Attitudes towards English as a possible lingua franca in Switzerland, York Papers in Linguistics 14, s. 3-17.

DürmüLLER U., 1992, The changing status of English in Switzerland, w: U. Ammon, M. Hellinger (red.), Status change of languages, Berlin-New York: Mouton de Gruyter, s. 355-370. 
Dürmüller U., 1994, Multilingual talk or English only? The Swiss experience, Sociolinguistica 8 , s. 44-64.

Dürmüller U., 2002, English in Switzerland: From foreign language to lingua franca, w: D. Allerton, P. Skandera, C. Tschichold (red.), Perspectives on English as a world language, Basel: Schwabe, s. 115-123.

FARAH I., 1997, Ethnography of communication, w: N. H. Hornberger, D. Corson (red.), Research methods in language and education. Encyclopedia of language and education, t. 8, Boston: Kluwer Academic Press, s. 125-133.

FASOLD R., 1984, The sociolinguistics of society, Oxford: Blackwell.

FishmAN J. A., 1972a, Domains and the relationship between micro- and macro-sociolinguistics, w: J. Gumperz, D. Hymes (red.) Directions in sociolinguistics: Ethnography of communication, New York: Holt, Rinehart and Winston, s. 435-453.

Fishman J. A., 1972b, The sociology of language: An interdisciplinary social science approach to language in society, Rowley: Newbury.

Fishman J. A., 1997, The sociology of language, w: N. Coupland, A. Jaworski (red.), Sociolinguistics: A reader and coursebook, London: Macmillan Press, s. 25-30.

GaL S., 2007, Multilingualism, w: C. Llamas, L. Mullany, P. Stockwell (red.), The Routledge companion to sociolinguistics, London-New York: Routledge, s. 149-156.

GARDNER R. CH., 1985, Social psychology and second language learning: The role of attitudes and motivation, London: Edward Arnold.

Gardner R. Ch., Lambert W. E., 1972, Attitudes and motivation in second language learning, Rowley: Newbury House Publishers.

Garrett P., 2007, Language attitudes, w: C. Llamas, L. Mullany, P. Stockwell (red.), The Routledge companion to sociolinguistics, London-New York: Routledge, s. $116-121$.

Garrett P., Coupland N., Williams A., 2006, Investigating language attitudes: Social meanings of dialect, ethnicity and performance, Cardiff: University of Wales Press.

Graddol D., 2001, The future of English as a European language, The European English Messenger 10 (2), s. 47-55.

Graddol D., 2006, English next: Why global English may mean the end of 'English as a foreign language', London: British Council.

Grin F., 2001, English as economic value: Facts and fallacies, World Englishes 20, s. $65-78$.

Herman S., 1970, Explorations in the social psychology of language choice, w: J. A. Fishman (red.), Readings in the sociology of language, Paris: Mouton, s. 492-511.

KiRKPATRICK A., 2006, Which model of English: Native speaker, nativized or lingua franca?, w: M. Saraceni, R. Rubdy (red.), English in the world: Global rules, global roles, London: Continuum Press, s. 71-83. 
Kristiansen T., 2011, Attitudes, ideology and awareness, w: R. Wodak, B. Johnstone, P. Kerswill (red.), The SAGE handbook of sociolinguistics, Los Angeles-London: SAGE Publications Ltd., s. 265-278.

McGroarty M., 1996, Language attitudes, motivation, and standards, w: S. L. McKay, N. H. Hornberger (red.), Sociolinguistics and language teaching, Cambridge: Cambridge University Press, s. 3-46.

NeLDE P. H., 1989, Ecological aspects of language contact or how to investigate linguistic minorities, Journal of Multilingual and Multicultural Development 10 (1), s. $73-86$.

Paulston CH. B. (red.), 1988, International handbook of bilingualism and bilingual education, New York: Greenwood Press.

PrCIC T., 2003, Is English still a foreign language?, The European English Messenger 12 (2), s. 35-37.

Seidlhofer B., 2004, Research perspectives on teaching English as a lingua franca, Annual Review of Applied Linguistics 24, s. 209-239.

Spolsky B., 2004, Language policy, Cambridge: Cambridge University Press.

Wardhaugh R., 2002, An introduction to sociolinguistics (Wyd. 4), Oxford: Blackwell.

Williams F., 1974, The identification of linguistic attitudes, International Journal of the Sociology of Language 3, s. 21-32.

Zabrocki L., 1972, Z teorii socjolingwistyki, Biuletyn Polskiego Towarzystwa Językoznawczego 30, s. 17-25.

ZuengLeR J., 1989, Identity and interlanguage development and use, Applied Linguistics 10 (1), s. 80-96.

\section{On language pragmatism in Switzerland in the context of English: A macro-sociolinguistic perspective}

( su m mary)

By adopting the macrolevel approach of both social and linguistic analysis, I intend to explore the problem of language attitudes and language choice at the interface of society and language. The issues connected with language behaviour, i.e. attitudes and reactions of the Swiss towards English, now seem to be ripe for a more detailed study. To this end I have carried out a research that examines the use of English in Switzerland from a multilingual perspective based on a corpus of 400 interviews collected in the German speaking canton of Zurich. 